\title{
Dependence of Serotonergic and Other Nonadrenergic Enteric Neurons on Norepinephrine Transporter Expression
}

\author{
Zhishan Li, ${ }^{1}$ Marc G. Caron, ${ }^{3}$ Randy D. Blakely, ${ }^{4}$ Kara G. Margolis, ${ }^{2}$ and Michael D. Gershon ${ }^{1}$ \\ Departments of ${ }^{1}$ Pathology and Cell Biology and ${ }^{2}$ Pediatrics, Columbia University, New York, New York 10032, ${ }^{3}$ Department of Cell Biology and \\ Neurobiology, Duke University, Durham, North Carolina 27710, and ${ }^{4}$ Department of Pharmacology and Psychiatry and Center for Molecular Neuroscience, \\ Vanderbilt University, Nashville, Tennessee 37232
}

The norepinephrine transporter (NET), which is expressed on the plasma membranes of noradrenergic neurons, is important in terminating neurotransmission. The noradrenergic sympathetic neurons that innervate the bowel express NET, but they are extrinsic and their cell bodies are not components of the enteric nervous system (ENS). Subsets of neurons were nevertheless found in the murine ENS that express transcripts encoding NET, NET protein, and dopamine $\beta$-hydroxylase; these neurons lack tyrosine hydroxylase (TH) and thus are not catecholaminergic. Enteric NET expression, moreover, preceded the ingrowth of sympathetic axons during development and did not disappear when the gut was extrinsically denervated. Transiently catecholaminegic (TC), neural crest-derived precursors of enteric neurons expressed NET at embryonic day 10 (E10) and NET expression in the fetal gut peaked coincidentally with early neurogenesis at E12. Serotonergic neurons, which are born early from TC progenitors, were found to express NET in the adult ENS, as did also other early-born neurons containing calretinin or neuronal nitric oxide synthase (nNOS) immunoreactivities. NET was not expressed in TH-immunoreactive dopaminergic neurons, which are born perinatally. Genetic deletion of NET almost eliminated tryptophan hydroxylase 2 expression and significantly reduced the numbers of total, 5-HT- and calretinin-immunoreactive enteric neurons, without affecting the immunoreactivities of nNOS or TH. These observations indicate that TC precursors of subsets of noncatecholaminergic enteric neurons express NET that persists in the successors of these cells despite their loss of TH. NET expression is essential for development and/or survival of some (5-HT- and calretinin-expressing), but not all (nNOS-expressing), of these neurons.

\section{Introduction}

The enteric nervous system (ENS), which contains a larger and more phenotypically diverse population of neurons than other peripheral ganglia, is unique in its ability to function independently of CNS input (Furness, 2006; Gershon and Ratcliffe, 2006). Serotonergic (Gershon and Tack, 2007; Gershon, 2009; Neal et al., 2009) and dopaminergic (Li et al., 2004, 2006) neurons are present in the ENS but not in other autonomic ganglia. Although the ENS contains norepinephrine (NE) as well as 5-HT and dopamine (DA), NE is not found in intrinsic neurons but is restricted to nerves that project to the bowel from sympathetic ganglia.

The ENS is formed by émigrés from the neural crest (Le Douarin and Kalcheim, 1999; Gershon and Ratcliffe, 2006). The enteric crest-derived cell (ENCDC) population that colonizes the bowel is multipotent (Sieber-Blum and Cohen, 1980; Ito and Sieber-Blum, 1993; Sieber-Blum et al., 1993; Sextier-SainteClaire Deville et al., 1994), although individual ENCDCs may become committed before migrating to the gut (Pham et al., 1991; Henion and Weston, 1997; Reedy et al., 1998a,b). The de-

Received May 3, 2010; revised Sept. 16, 2010; accepted 0ct. 13, 2010.

This work was supported by National Institutes of Health Grants NS12969 and NS15547.

Correspondence should be addressed to Dr. Zhishan Li, Department of Pathology and Cell Biology, Columbia University, College of Physicians and Surgeons, 630 West 168th Street, New York, NY 10032. E-mail: ZL64@columbia.edu.

DOI:10.1523/JNEUROSCI.2276-10.2010

Copyright $\odot 2010$ the authors $\quad 0270-6474 / 10 / 3016730-11 \$ 15.00 / 0$ velopment of the unique features of the ENS depends on intrinsic ENCDC properties and on microenvironmental cues that ENCDCs encounter while migrating to and within the bowel (Gershon and Ratcliffe, 2006; Hao and Young, 2009; Laranjeira and Pachnis, 2009). Although ENS development has been studied extensively, particularly with respect to the pathogenesis of Hirschsprung's disease (aganglionosis of the terminal gut), the molecular determinants of individual enteric neuronal phenotypes are poorly understood.

Some precursors of enteric neurons are transiently catecholaminergic (TC) while still proliferating (Teitelman et al., 1981; Gershon et al., 1984). These Ascl1-dependent (formerly called Mash-1) cells lose tyrosine hydroxylase (TH), and thus their ability to synthesize catecholamines, when they terminally differentiate into serotonergic and other, not-yet-identified types of enteric neurons (Blaugrund et al., 1996). In contrast to serotonergic neurons, which are born early [embryonic day 8.5 (E8.5) to E15] (Pham et al., 1991), enteric dopaminergic neurons are born late (perinatally) (Chalazonitis et al., 2008), are Ascl1 independent, and are not TC cell derived (Li et al., 2004). Although TC cells accumulate $\left[{ }^{3} \mathrm{H}\right] \mathrm{NE}$ (Gershon et al., 1984), the responsible transporter has not been defined. The NE transporter (NET) (SLC6A2), the dopamine transporter (DAT), and organic cation transporters (OCTs) (Gründemann et al., 1998) can transport NE. Importantly, NET expression during sympathetic neuronal development has been linked to acquisition of the noradrenergic phenotype, and ablation of the murine NET gene leads to the 
deregulation of signaling pathways that are involved in ENS development (Hu et al., 2009).

The current experiments were performed to determine whether TC cells express NET and, if they do, whether mature TC-cell-derived neurons retain NET to support cell differentiation and/or survival. Observations indicate that TC cells express NET, which is retained in subsets of neurons derived from them; NET expression is essential for the development of a full complement of enteric neurons, specifically including serotonergic or calretinin-containing cells.

\section{Materials and Methods}

Animals and tissue preparation. Experiments were performed with fetal and adult mice of either sex. CD-1 mice, which breed well and have been used previously to study ENS development, C57BL/6 mice (25-30 g; Charles River), and transgenic C57BL/6 mice that lack NET [NET knockout mice (NETKO mice)] (Xu et al., 2000) were used. $\mathrm{CO}_{2}$ inhalation was used to kill adult animals. The Animal Care and Use Committee of Columbia University approved this procedure. The brain, stomach, duodenum, ileum, and proximal and distal colon were removed from the animals and processed for molecular and histological studies. Fetal mice were removed from pregnant dams at E10, E12, E14, E16, and E18. Newborn mice were also investigated. The day at which a vaginal plug was found was designated as day 0 of gestation.

RNA extraction and preparation of cDNA. Tissues were collected in PBS $(0.9 \% \mathrm{NaCl}$ in $0.01 \mathrm{~m}$ sodium phosphate buffer, $\mathrm{pH} 7.4)$ that had been treated with $0.1 \%$ diethyl pyrocarbonate (DEPC-PBS). Fetal gut was collected in ice-cold HBSS and stored in RNA Later (Ambion). After the wall of each piece of gut was opened, the tissue was cleaned with DEPCPBS, transferred to Trizol (Invitrogen) for extraction of total RNA according to the instructions of the manufacturer, and thereafter stored for additional use at $-80^{\circ} \mathrm{C}$. cDNA was prepared from $3 \mu \mathrm{g}$ of total RNA by reverse transcription in a $30 \mu \mathrm{l}$ reaction volume with $0.5 \mu \mathrm{g}$ of random hexamer primers, $0.5 \mathrm{~mm}$ dNTPs, $40 \mathrm{U}$ of Rnasin, and $400 \mathrm{U}$ of Maloney murine leukemia virus reverse transcriptase (Promega).

PCR. Pairs of oligonucleotide primers for amplification of cDNA encoding $\beta$-actin or NET were designed from published mouse cDNA sequences. The programs used for PCR amplification with each primer pair are listed in supplemental Table 1 (available at www.jneurosci.org as supplemental material). The identities of all PCR products were confirmed by sequence analysis. For this purpose, PCR products were subcloned into pGEM-T Easy vectors (Promega) by using the TA-cloning kit (Invitrogen). Inserts in two individual clones were sequenced by the dideoxynucleotide-chain termination method (GENEWIZ). The sequences of the PCR products obtained from the brain and gut were found to be identical to those of the appropriate regions of the GenBank sequences of the amplified cDNAs.

Real-time PCR. Real-time (RT)-PCR was used to quantify transcripts encoding NET in regions of the adult and fetal murine bowel and in the brains of adult mice as described previously (Li et al., 2004). The abundance of transcripts encoding NET was normalized to that of $\beta$-actin, a housekeeping gene that is not thought to be subject to regulation. Transcripts encoding $\beta$-actin in samples of mouse gut were first quantified by RT-PCR with the SYBR Green Jumpstart Taq ReadyMix (Sigma) using a LightCycler instrument (Roche Diagnostics). Plasmid DNA encoding NET or $\beta$-actin was serially diluted to prepare standard curves. These dilutions ranged from $1 \mathrm{pg}$ to $10 \mathrm{ng}$ in five series, each of which covered a 10 -fold range. Amplifications were performed in a final volume of $20 \mu \mathrm{l}$ of a commercial reaction mixture (Sigma) that contained TaqDNA polymerase, reaction buffer, dNTPs in which dTTP is replaced by dUTP, SYBR Green I dye, and $\mathrm{MgCl}_{2}$. The primers for the amplification of cDNA encoding each gene were used at a final concentration of $0.3 \mu \mathrm{M}$. The final concentration of $\mathrm{MgCl}_{2}$ was $4.5 \mathrm{~mm}$ for the amplification of $\beta$-actin and $3 \mathrm{~mm}$ for NET, TH, and tryptophan hydroxylase 2 (TPH2). Two microliters of either the serially diluted plasmid DNA (standards) or the cDNA prepared from tissue was added to this mixture. The standards and the cDNA from tissues were simultaneously subjected to real-time PCR analysis in parallel capillary tubes. The PCR reactions were per-
Table 1. Effect of NETKO on densities of sets of enteric neurons

\begin{tabular}{lccc}
\hline & \multicolumn{2}{l}{ Packing density (neurons/mm ${ }^{2}$ ) } & \\
\cline { 2 - 3 } Type of neuron & WT & NETKO & \\
\hline Total (HuC/D) & $261 \pm 17$ & $187 \pm 15$ & $<0.02$ \\
Serotonergic (5-HT) & $0.94 \pm 0.09$ & $0.34 \pm 0.08$ & $<0.005$ \\
Calretinin & $84.0 \pm 6.4$ & $56.8 \pm 5.7$ & $<0.02$ \\
Nitrergic (nNOS) & $17.7 \pm 3.4$ & $26.3 \pm 3.4$ & NS \\
Dopaminergic (TH) & $2.1 \pm 0.5$ & $1.9 \pm 0.5$ & NS
\end{tabular}

Data were derived from analyses of the small intestinal myenteric plexus of five WT and five NETKO mice. In each preparation of each type of immunostainings, neurons were counted in $10 \mathrm{~mm}^{2}$ of tissue in a flat whole mount of longitudinal muscle with attached myenteric plexus.

formed according to the programs in supplemental Table 1 (available at www.jneurosci.org as supplemental material). The appearance of double-stranded DNA was quantified by measuring the fluorescence of SYBR Green after each step of elongation. A melting point analysis was finally performed to improve the sensitivity and specificity of amplification reactions detected with the SYBR Green I dye; samples were incubated at $95^{\circ} \mathrm{C}$ for $0 \mathrm{~s}$, at $67^{\circ} \mathrm{C}$ for $\beta$-actin and $\mathrm{TH}, 68^{\circ} \mathrm{C}$ for $\mathrm{TPH} 2,70^{\circ} \mathrm{C}$ for NET for $15 \mathrm{~s}$, and then from $67^{\circ} \mathrm{C}, 68^{\circ} \mathrm{C}$, or $70^{\circ} \mathrm{C}$ to $95^{\circ} \mathrm{C}$ with a transition rate of $0.2^{\circ} \mathrm{C} / \mathrm{s}$. Data were analyzed with computer assistance using the LightCycler software.

Immunocytochemistry. Segments of the ileum of adult mice were collected in PBS to which the muscle relaxant nicardipine had been added to prevent muscle spasm ( $10^{-6} \mathrm{M}$; Sigma) (Li et al., 2004). The contents were flushed with PBS, and the preparations were opened along the mesenteric border. For whole mounts, the tissue was stretched and pinned flat on balsa wood with the mucosal surface down. Specimens were fixed for $2 \mathrm{~h}$ at room temperature with $4 \%$ formaldehyde (from paraformaldehyde; pH 7.4) and washed three times with PBS for a total of $30 \mathrm{~min}$. The gut wall was dissected to prepare laminar preparations of longitudinal muscle with adherent myenteric plexus (LMMP) or submucosa (containing the submucosal plexus). Fetal mice (E10 and E12) and adult intestines were also fixed with 4\% formaldehyde for 3-6 h and washed with PBS, cryoprotected overnight at $4^{\circ} \mathrm{C}$ with $30 \%$ sucrose in PBS containing $0.1 \%$ sodium azide, embedded in OCT compound (Tissue Tek; Sakura Finetec), and sectioned at $10 \mu \mathrm{m}$ in a cryostat microtome. Sections were air dried on slides for $1 \mathrm{~h}$ at room temperature.

For immunostaining, sections were permeabilized and blocked by incubation for $30 \mathrm{~min}$ at room temperature with 1\% Triton X-100 in PBS (PBST) containing 10\% normal horse or goat serum (corresponding to the host species used to generate secondary antibodies) to prevent nonspecific staining. The whole mounts and sections were incubated with primary antibodies overnight (supplemental Table 2, available at www. jneurosci.org as supplemental material), at either room temperature or at $4^{\circ} \mathrm{C}$. Primary antibodies from different species were used to label two antigens simultaneously (supplemental Table 2, available at www. jneurosci.org as supplemental material). As a control for the specificity of antibodies to NET, antibodies to NET were applied to tissue from transgenic mice that lack NET. No nonspecific NET immunoreactivity was detected (see Results, Fig. 7B). For 5-HT immunocytochemistry, no preloading with 5-HT was used to ensure that only endogenous 5-HT would be detected. After washing with PBS for three times for $10 \mathrm{~min}$, the tissue was incubated with appropriate affinity-purified species-specific secondary antibodies for $2 \mathrm{~h}$. The working concentrations of the secondary antibodies used for immunofluorescence were as follows: goat antirabbit Alexa Fluor 594 (diluted 1:200; Invitrogen), biotin-labeled donkey anti-rabbit (diluted 1:200; Jackson ImmunoResearch), donkey anti-goat Alexa Fluor 594 (diluted 1:200; Invitrogen), and donkey anti-sheep Alexa Fluor 488 (diluted 1:200; Invitrogen).

Immunostained tissue was viewed with a Leica DMRXA2 microscope. For epifluorescence, the L5 (Alexa Fluor 488) and M2 (Alexa Fluor 594) dichroic mirror/filter combinations were used; there was no crossdetection of either fluorophore. Images were captured digitally with a cooled CCD camera (Q Imaging) operated by a Macintosh computer using commercial software (Volocity; Improvision). Contrast was adjusted by using the Volocity 5.2 software, which was also used to analyze double labeling by superimposing images. Bright-field images were cap- 
tured with the same microscope, camera, and computer software, except that red-green-blue filters were interposed between the microscope and the camera to permit color imaging. Pictures were sized and assembled using Adobe Photoshop software for the Macintosh computer.

In situ hybridization. Transcripts encoding NET were located in tissue by using methods of in situ hybridization that have been described previously (Schaeren-Wiemers and Gerfin-Moser, 1993). Briefly, mouse gut was dissected in ice-cold DEPC-PBS, stretched, and pinned flat on autoclaved balsa wood. Preparations were fixed on their supports in a freshly made, ice-cold solution containing $4 \%$ formaldehyde (from paraformaldehyde) for $1.5 \mathrm{~h}$. After washing with DEPC-PBST, the preparations were incubated overnight with $30 \%$ sucrose/DEPC-PBS at $4^{\circ} \mathrm{C}$, embedded in OCT, and frozen in liquid $\mathrm{N}_{2}$. Sections $(12 \mu \mathrm{m})$ were cut at $-20^{\circ} \mathrm{C}$ in a cryostat microtome and thaw mounted onto Colorfrost Plus slides (Thermo Fisher Scientific). Sections were air dried for 20-60 min, rinsed in DEPC-PBST for $5 \mathrm{~min}$, postfixed with $4 \%$ formaldehyde at room temperature for $15 \mathrm{~min}$, and washed again with DEPC-PBST to eliminate residual fixative. Sections were then permeabilized with $1.0 \mu \mathrm{g} / \mathrm{ml}$ proteinase $\mathrm{K}$ in DEPC-PBS, washed with $2.0 \mathrm{mg} / \mathrm{ml}$ glycine in DEPC-PBST, equilibrated in $0.1 \mathrm{M}$ triethanolamine, $\mathrm{pH} 8.0$, for $2 \mathrm{~min}$, acetylated for $10 \mathrm{~min}$ in $0.25 \%$ acetic anhydride in $0.1 \mathrm{M}$ triethanolamine, and washed in DEPCPBST. Sections were incubated at $68^{\circ} \mathrm{C}$ for $1 \mathrm{~h}$ in prehybridization buffer, containing 50\% formamide (Thermo Fisher Scientific), $5 \times$ SSC, $5 \times$ Denhardt's solution, $0.25 \mathrm{mg} / \mathrm{ml}$ yeast tRNA (Roche), $500 \mu \mathrm{g} / \mathrm{ml}$ salmon sperm DNA (Sigma), and $100 \mu \mathrm{g} / \mathrm{ml}$ heparin (Sigma). For hybridization, sections were incubated in the same buffer with $100 \mathrm{ng} / \mathrm{ml}$ sense or antisense digoxigenin-labeled riboprobes for NET for $16 \mathrm{~h}$. The slides were washed in $2 \times$ SSC containing $0.1 \%$ SDS at room temperature for $5 \mathrm{~min}$ twice, in $0.1 \times$ SSC containing $0.1 \% \mathrm{SDS}$ at $68^{\circ} \mathrm{C}$ for $30 \mathrm{~min}$ twice, and in $2 \times \mathrm{SSC}$ at room temperature for $5 \mathrm{~min}$. Sections were blocked with $10 \%$ goat serum in TBS containing $0.05 \%$ Tween 20 (TBST) for $1 \mathrm{~h}$ at room temperature and incubated for $2 \mathrm{~d}$ at room temperature with fluorescein isothiocyanate-labeled Fab fragments of sheep antibodies to digoxigenin (Roche) (diluted 1:1500, in TBST containing $10 \%$ goat serum blocking solution). Sections were then exposed to antibodies to NET or 5-HT and appropriate secondary antibodies as described above. Finally, the sections were coverslipped in a 1:2 mixture of $0.5 \mathrm{~m}$ bicarbonate buffer, $\mathrm{pH} 8.6$, and glycerol.

Denervation of extrinsic axons. The extrinsic innervation to segments of small intestine was ablated in 10 mice. The animals were anesthetized with a subcutaneous injection of a mixture of ketamine $(90 \mathrm{mg} / \mathrm{kg})$ and xylazine $(5 \mathrm{mg} / \mathrm{kg})$. The depth of anesthesia was monitored by checking the withdrawal reflex evoked by gentle squeezing of a toe with a pair of forceps. The surgical procedure used for denervation was similar to that used previously in the guinea pig small intestine (Li et al., 1998; Pan and Gershon, 2000). Two loops of intestine were denervated in each animal. For each denervation, a loop of ileum supplied by a single mesenteric artery and its branches was selected. On the mesenteric artery, the vessel was manipulated at a site that was $2-3 \mathrm{~cm}$ distant from the intestinal wall. All of the nerve fiber bundles at this site that could be seen to follow the mesenteric artery and vein that supplied the loop of bowel were stripped away using fine forceps under microscopic control. To ablate any nerve fibers that were not severed by this procedure, the pair of vessels were painted with a small amount of $80 \%$ phenol in distilled water, which was applied by a small swab under microscopic control. The excess phenol was then thoroughly washed away with $0.9 \% \mathrm{NaCl}$. The denervated region of the gut was marked with a loose ligature placed around its vascular supply. The bowel was finally returned to the abdominal cavity and the abdomen was closed. After surgery, pain was minimized by the subcutaneous administration of buprenorphine $(1 \mathrm{mg} / \mathrm{kg})$. The animals were then allowed to recover from anesthesia and given access to food and water ad libitum. The mice were euthanized by $\mathrm{CO}_{2}$ inhalation 1 week after surgery. The two denervated loops of ileum and a single loop of normal small intestine (as control) were removed from each animal and analyzed by RT-PCR and immunocytochemistry. The sympathetic innervation of the gut was used as a marker of the extrinsic innervation and was assessed to evaluate the extent of denervation. To do so, TH was demonstrated immunocytochemically to visualize the characteristic network of sympathetic terminals in the enteric plexuses. The denervated and control loops of gut were each divided into two equal pieces. One piece of tissue was used for RNA isolation and the other part for immunocytochemistry.

Chemical sympathectomy. Four CD-1 mice were subjected to chemical sympathectomy, and another four mice served as controls. To perform the sympathectomy, $80 \mathrm{mg} / \mathrm{kg}$ 6-hydroxydopamine hydrobromide (Sigma) in $0.1 \%$ ascorbic acid was injected intraperitoneally each day for 3 consecutive days. One day later, mice were euthanized as described above. Protein was extracted from the brain and the proximal ileum and used for immunoblots. The distal ileum was fixed in $4 \%$ formaldehyde to verify immunocytochemically the completeness of the sympathetic denervation of the bowel (see above).

Immunoblotting. Tissue was harvested, washed with PBS, and homogenized in $300 \mu$ l of $50 \mathrm{~mm}$ Tris buffer, pH 7.4, containing EDTA (1.0 mM), EGTA (2.0 mM), phenylmethanesulfonyl fluoride (1.0 mM), aprotinin (100 $\mathrm{mg} / \mathrm{ml})$, and leupeptin $(100 \mathrm{mg} / \mathrm{ml})$. The homogenate was centrifuged at $10,000 \times g$ for $30 \mathrm{~min}$ at $4^{\circ} \mathrm{C}$ to separate a membrane fraction (pellet) from the cytosol. The pellet was solubilized in the same buffer containing Triton X-100 (1.0\%). Proteins (50 $\mu \mathrm{g})$ were separated by $8.5 \%$ SDS-PAGE. After separation, the proteins were electroblotted onto polyvinylidene difluoride membranes and immersed in blocking buffer containing 5\% nonfat dry milk in Tris-base sodium chloride buffer for $30 \mathrm{~min}$ at room temperature. The blot was washed with TBST and finally incubated overnight at $4^{\circ} \mathrm{C}$ with rabbit polyclonal antibodies to NET (\#43411, diluted 1:3000 in 3\% nonfat dry milk) (supplemental Table 2, available at www.jneurosci.org as supplemental material) or with rabbit polyclonal antibody to $\beta$-actin (Sigma) (diluted 1:1000 in 3\% nonfat dry milk). After washing with TBST, the blot was incubated with goat HRP-labeled secondary antibodies to rabbit IgG (Vector Laboratories) for $1 \mathrm{~h}$ at room temperature. The blot was finally washed with TBST and developed with a chemiluminescent substrate (Pierce).

Statistical analysis. Differences between means were compared by Student's $t$ test. A $p$ value of $<0.05$ was considered significant.

\section{Results}

\section{Transcripts encoding NET are expressed in the mouse} stomach and small and large intestines

The regional distribution of transcripts encoding NET was studied in mouse gut. Total RNA was extracted from stomach, duodenum, ileum, and proximal (ascending and transverse) and distal (descending, sigmoid, rectum) colon. The abundance of transcripts encoding NET in each region of the bowel, relative to that of transcripts encoding $\beta$-actin, was quantified by real-time PCR. Transcripts encoding NET were found in all sampled regions of the gut; moreover, no significant difference was found in the abundance of transcripts encoding NET in any specific region of the bowel (Fig. $1 A, B)$. Because sympathetic neurons are extrinsic to the gut, transcripts found to be present in the bowel are unlikely to have been synthesized by sympathetic neurons and thus probably represent endogenous enteric NET expression. Sympathetic neurons, however, are a prominent source of NET, and their axons project to the gut; therefore, to determine whether transcripts encoding NET are present in the enteric terminals of sympathetic axons, the enteric expression of NET was examined 1 week after extrinsic denervation. To confirm that denervation was successful, TH was demonstrated in a laminar whole mount of the LMMP prepared from a small portion of the denervated segment (Fig. 1C). The varicose THimmunoreactive sympathetic nerves disappeared from the denervated tissue, leaving only the rare dopaminergic neurons of the myenteric plexus and their readily identified neurites, which also contain TH immunoreactivity. RT-PCR was used to analyze transcripts encoding NET and $\beta$-actin in the remainder of the denervated loop of bowel (Fig. $1 D$ ). Enteric expression of transcripts encoding NET was found to persist after extrinsic denervation of the bowel, and the relative abundance of transcripts encoding NET did not change. These observations support the idea that enteric expression of NET is a property of intrinsic components of the bowel wall rather than its sympathetic innervation. 
A

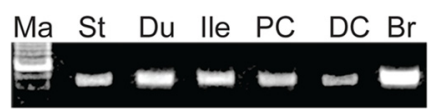

B

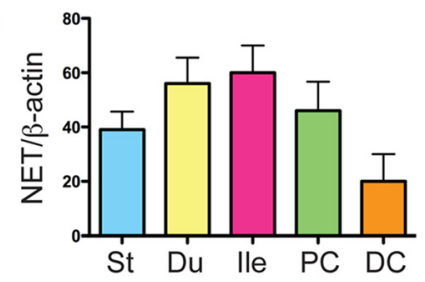

C

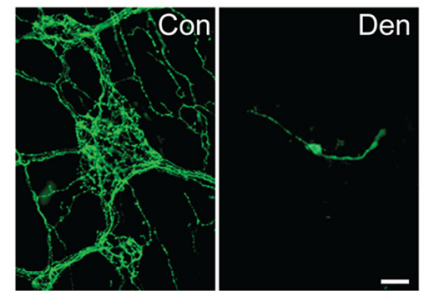

D NET

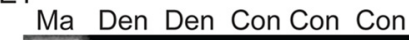

$\beta$-actin

$E$

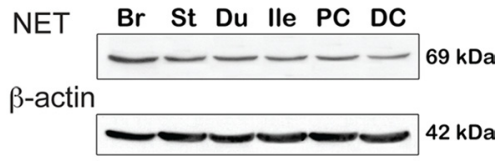

$\mathbf{F}$

NET

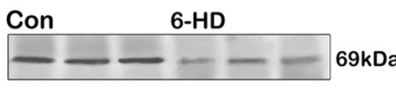

G

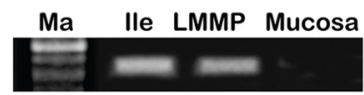

Figure 1. NET expression is found throughout the gut, is intrinsic to the bowel, remains after sympathectomy, and is restricted to layers of the gut that contain ganglia. $A$, Transcripts encoding NET detected regionally in the gut by RT-PCR. Ma, Markers; St, stomach; Du, duodenum; lle, ileum; $\mathrm{PC}$, proximal colon; $\mathrm{DC}$, distal colon; $\mathrm{Br}$, brain. $\boldsymbol{B}$, The abundance of transcripts encoding NET was quantified relative to that of $\beta$-actin in the same regions of the gut. $C$, Extrinsic denervation was performed by crushing perivascular nerves in the mesentery of mouse ileum. To verify that denervation has eliminated the sympathetic innervation, sympathetic nerves were studied immunocytochemically in proximal control (Con; left) and denervated (Den; right) segments of gut. TH immunoreactivity was demonstrated as a sympathetic marker. Oneweek after surgery, the prominent varicose sympathetic innervation seen in the control tissue (Con) was no longer evident in the denervated bowel (Den). A single dopaminergic neuron is visible in the myenteric plexus (Den). Scale bar, $50 \mu \mathrm{m}$. $\boldsymbol{D}$, Transcripts encoding NET are detectable in both denervated (Den; 2 mice illustrated) and control (Con; 3 mice illustrated) segments of bowel. $\boldsymbol{E}$, NET-immunoreactive protein detected regionally in Western blots. Ma, Markers; St, stomach; Du, duodenum; lle, ileum; PC, proximal colon; DC, distal colon; Br, brain. $\boldsymbol{F}$, One week after chemical sympathectomy with 6-hydroxydopamine (6-HD), NETimmunoreactive protein is still detectable in Western blots. Tissue from three control and three 6-hydroxydopamine-treated mice are illustrated. G, Transcripts encoding NET can be detected in whole ileum and LMMP but not in the mucosa.
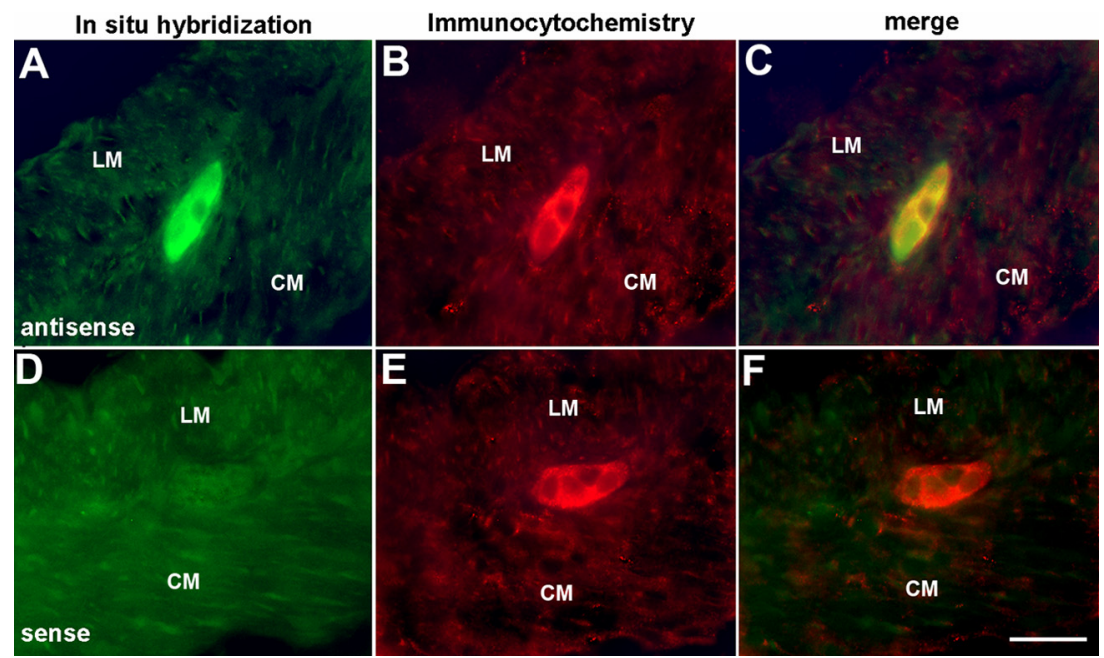

Figure 2. The locations of transcripts encoding NET and NET immunoreactivity are coincident in enteric neurons. $\boldsymbol{A}$, In situ hybridization with antisense riboprobe demonstrates the location of transcripts encoding NET. The section passes through a myenteric ganglion. The locations of the longitudinal muscle (LM) and circular muscle (CM) layers are indicated. $\boldsymbol{B}$, NET immunoreactivity in the same section of adult small intestine shown in $\boldsymbol{A}$. $\boldsymbol{C}$, Merged image of $\boldsymbol{A}$ and $\boldsymbol{B}$. The same three neurons that contain transcripts encoding NET are also NET immunoreactive. $\boldsymbol{D}$, In situ hybridization with sense probe fails to demonstrate transcripts encoding NET. Again, a section passes through a myenteric ganglion. The locations of the longitudinal muscle (LM) and circular muscle (CM) layers are indicated. $E$, NET immunoreactivity. $\boldsymbol{F}$, Merged image of $\boldsymbol{D}$ and $\boldsymbol{E}$. The NET-immunoreactive neurons have not been labeled by the sense probe. Scale bar, $25 \mu \mathrm{m}$.

\section{NET is expressed by intrinsic enteric neurons}

Experiments using Western blotting were performed to verify that NET protein, as well as transcripts, is present in the gut. The brain was also analyzed as a positive control. NET-immunoreactive pro- tein was detected in the stomach, duodenum, ileum, and proximal and distal colon (Fig. 1E). The electrophoretic mobility of NET-immunoreactive protein extracted from the bowel was identical to that of the brain; moreover, the antibody used, 43411, does not reveal immunoreactivity in tissue of NETKO mice (see Fig. 7B). In contrast to transcripts encoding NET, which would not be expected to be present in sympathetic axons within the gut, NET protein would be anticipated to be concentrated in the plasma membranes of sympathetic fibers that project to targets within the bowel. A chemical sympathectomy was therefore performed with 6-hydroxydopamine to enable NET-immunoreactive protein to be analyzed in sympathectomized gut. Although 6-hydroxydopamine enters cells and cell processes by NET-mediated transmembrane transport, uptake of systemically administered 6-hydroxydopamine does not lesion nerve cell bodies. Sympathetic neurons thus survive in animals treated with 6-hydroxydopamine, although their terminal axons do not. Because sympathetic neurons survive, sympathetic axons regenerate soon after the administration of 6-hydroxydopamine (Finch et al., 1973). Although chemical sympathectomy did, as expected, decrease NET-immunoreactive protein in the gut, substantial NETimmunoreactive protein remained after chemical sympathectomy (Fig. $1 F$ ). These observations are consistent with the idea that intrinsic cells of the gut wall transcribe and translate NET.

RT-PCR was used to identify the layers of the bowel wall that express NET. The mucosa and LMMP were dissected and analyzed as separated laminar preparations (Fig. 1G). The whole ileum was also studied as a positive control. Transcripts encoding NET were detected in the whole ileum, and they were also identified in the LMMP. In contrast, transcripts encoding NET could not be found in the isolated mucosa. Because NET expression has been reported to occur in the endoderm (Ren et al., 2003), these observations on adult bowel suggest that NET expression is developmentally regulated and that endodermal expression of NET is transient. The presence of transcripts encoding NET in the LMMP of adult bowel is consistent with the idea that adult NET expression occurs in myenteric neurons. Immunocytochemistry and in situ hybridization were combined to identify the intrinsic sources of transcripts encoding NET and NETimmunoreactive protein in the adult bowel wall. These techniques were applied sequentially to sections of mouse ileum. Digoxigenin-labeled sense and antisense riboprobes were synthe- 
A

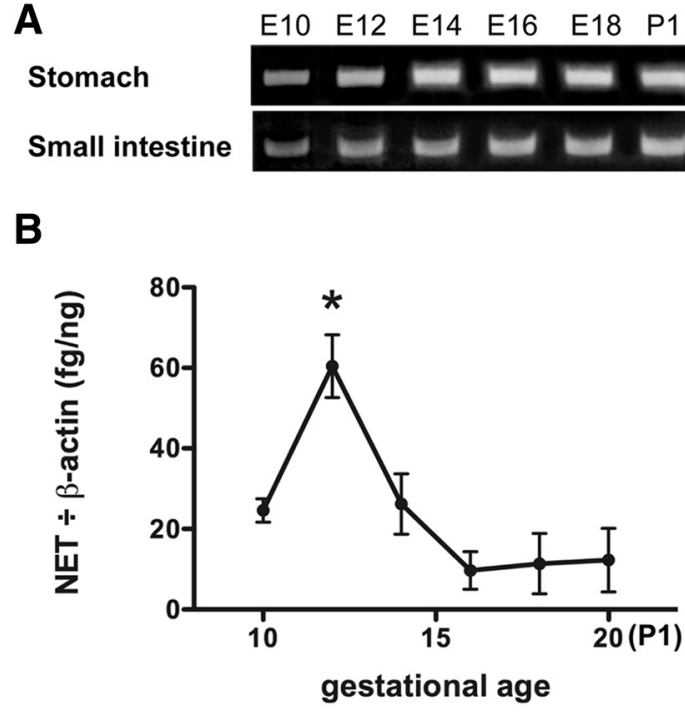

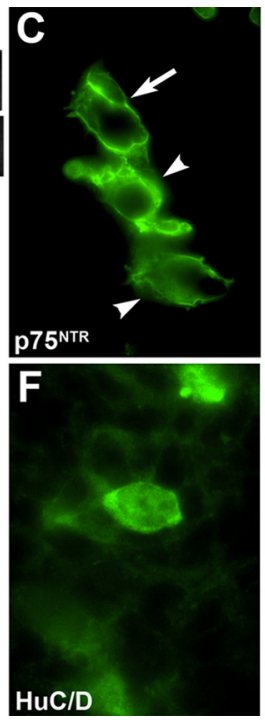
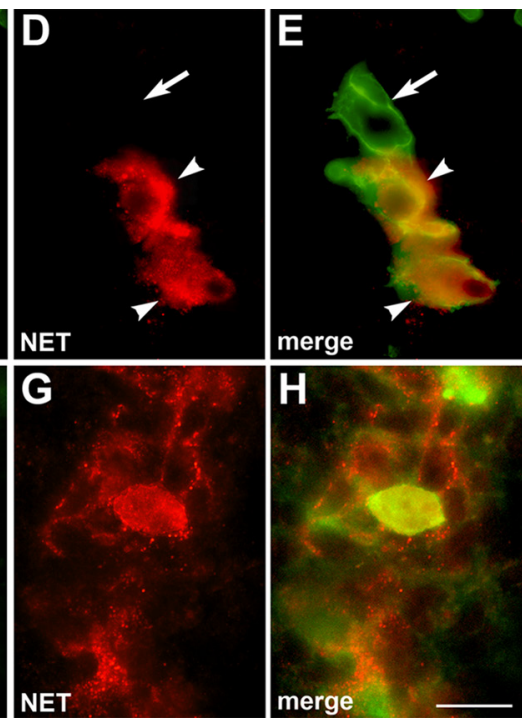

Figure 3. ENCDCs express NET before neuronal development but, after their differentiation, enteric neurons express NET. $\boldsymbol{A}$, Transcripts encoding NET can be detected in the developing stomach and small intestine from E10 through P1. $\boldsymbol{B}$, The abundance of transcripts encoding NET (relative to those encoding $\beta$-actin) peaks at E12 in the small intestine. $\boldsymbol{C}$, ENCDCs located in the fetal gut at E10 with antibodies to p75 ${ }^{\text {NTR }}$. Note the concentration of p75 ${ }^{\text {NTR }}$ immunoreactivity in plasma membranes. D, NET-immunoreactive cells located with antibodies to NET in the same section of E10 bowel illustrated in $\boldsymbol{C}$. $\boldsymbol{E}$, Merged image of $\boldsymbol{C}$ and $\boldsymbol{D}$. NET is expressed by some (arrowheads), but not all (arrow), p75 ${ }^{\text {NTR }}$-immunoreactive cells. $\boldsymbol{F}$, Neurons located in the fetal gut at E12 with antibodies to HuC/D. G, NET-immunoreactive cells located with antibodies to NET in the same section of E12 bowel illustrated in $\boldsymbol{F}$. $\boldsymbol{H}$, Merged image of $\boldsymbol{F}$ and $\boldsymbol{G}$. Hu and NET immunoreactivities are coincident. Scale bar, $25 \mu \mathrm{m}$.

sized for in situ hybridization and immunofluorescence with antibodies to digoxigenin was used to visualize bound probe (Fig. $2 A)$. NET-immunoreactive protein was located in the same sections with antibodies to NET (Fig. $2 B, E$ ). The antisense NET riboprobe and antibodies to NET were found to doubly label enteric neurons in both plexuses; moreover, the in situ localization of transcripts encoding NET was specific because no structures were labeled by the sense NET riboprobe (Fig. 2D). The coincident labeling of neurons by in situ hybridization and antibodies to NET was $100 \%$. No other structures in the wall of the bowel were labeled by either the antisense NET riboprobe or antibodies to NET. These data support the idea that intrinsic neurons are the sole source of NET transcripts in the adult gut. The coincident detection of NET immunoreactivity and transcripts in the same cells also verifies the specificity of the antibodies used to locate NET.

\section{NET is expressed and developmentally regulated in the} fetal bowel

RT-PCR was used to investigate NET expression as a function of age in the fetal gut. Transcripts encoding NET were detectable in the fetal stomach and small intestine at the earliest age examined, E10, and they continued to be expressed throughout fetal life (Fig. 3A). RT-PCR was used to quantify the abundance of transcripts encoding NET in the small intestine. This quantitation revealed that expression of NET in the fetal gut was developmentally regulated and that a sharp peak of NET expression occurred at E12 (Fig. 3B). The crest-derived precursors of enteric neurons are known to have colonized the fetal stomach and small intestine by E10, although terminally differentiated enteric neurons do not become detectable until E12 (Rothman and Gershon, 1982; Rothman et al., 1984; Young et al., 2003). Immunocytochemistry was thus used to determine whether NET immunoreactivity is expressed in the foregut by the $\mathrm{p} 75^{\mathrm{NTR}}$-immunoreactive crestderived cells that are found at E10 and by the Hu-immunoreactive neurons that develop from them at E12. At E10, all
NET-immunoreactive cells were colabeled with antibodies to p $75^{\text {NTR }}$, although the doubly labeled cells were a subset of the p75 ${ }^{\text {NTR }}$ population (Fig. $3 C-E$ ). At E12, NET-immunoreactive cells were colabeled with antibodies to $\mathrm{Hu}($ Fig. $3 F-H)$. These observations suggest that a subset of crest-derived neuronal precursors expresses NET and that NET-expressing neurons developing at E12 could account for the peak in NET transcript abundance that occurs at that age.

\section{Transiently catecholaminergic neuronal precursors express NET}

The Ascl1-dependent TC subset of enteric neuronal precursors is present in the bowel at E10 (Teitelman et al., 1981; Gershon et al., 1984; Baetge and Gershon, 1989). Because the uptake of NE by TC cells can be blocked by the tricyclic antidepressant desmethylimipramine (Baetge and Gershon, 1989), a potent NET inhibitor, these cells are likely to express NET and thus could account for the NET expressed before the onset of terminal neuron differentiation. We thus tested the hypotheses that TC cells express NET and that early-developing, NET-expressing neurons arise from TC precursors. TH immunoreactivity was used as a marker for TC cells. Although the progeny of TC cells downregulate TH expression, TH is not lost in the mouse until E15 (Gershon et al., 1984). It is regained much later when enteric dopaminergic neurons develop during the perinatal period ( $\mathrm{Li}$ et al., 2004). To test the idea that enteric NET expression is a property of TC cells, the E12 fetal stomach and small intestine were investigated with antibodies to TH and NET. The immunoreactivities of TH and NET were found to be coincident (Fig. $4 A-C$ ); all of the NETimmunoreactive cells in the bowel at E12 were TH immunoreactive. No NET immunoreactivity was detected in the endodermal epithelium at this age. The doubly labeled TH/NET-immunoreactive cells were all located in the outer gut mesenchyme in which the primordial ENS is located. A second marker for TC cells is dopamine- $\beta$-hydroxylase (DBH). To verify that NETexpressing cells were TC cells, therefore, the immunoreactivities 

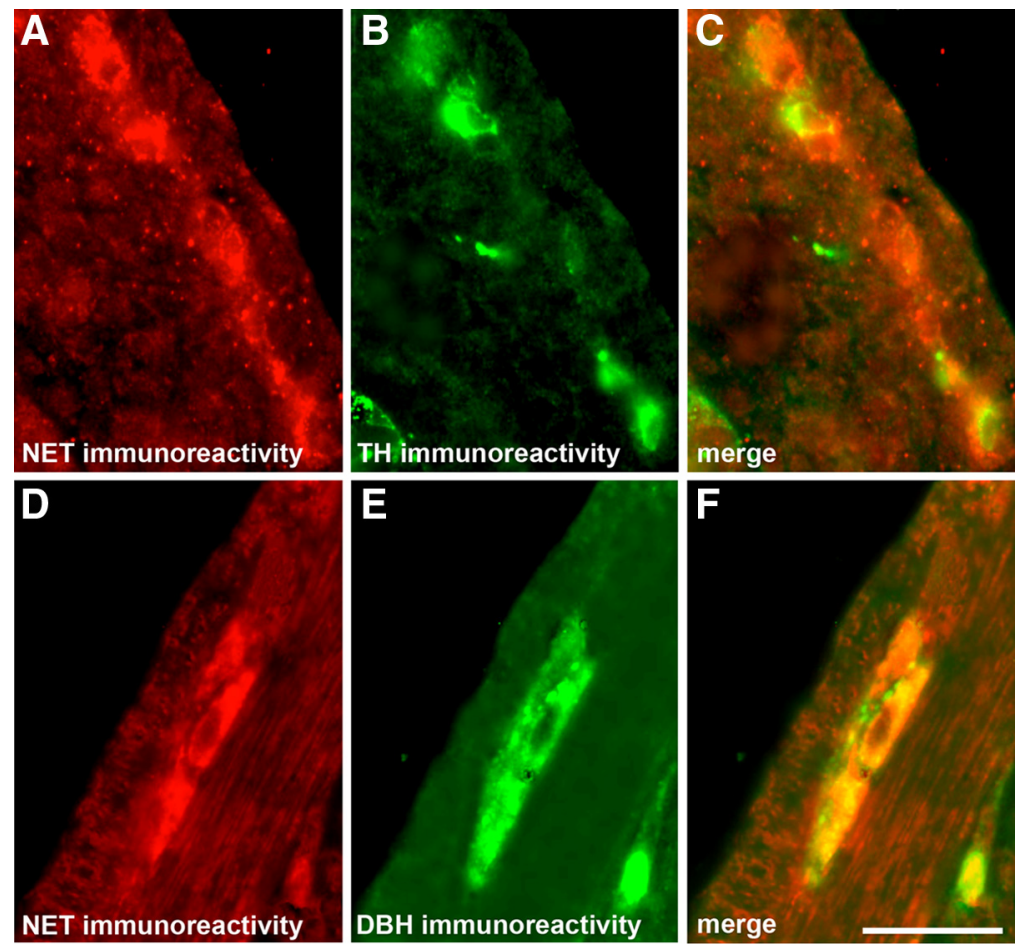

Figure 4. TC cells and neurons derived from them are NET immunoreactive. $A$, NET-immunoreactive cells located with antibodies to NET in E12 fetal intestine. $\boldsymbol{B}$, TC cells in the same section of E12 gut located with TH immunoreactivity as a marker. $\boldsymbol{C}$, Merged image of $\boldsymbol{A}$ and $\boldsymbol{B}$. D, NET-immunoreactive cells located with antibodies to NET in a section of adult small intestine. $\boldsymbol{E}$, DBH immunoreactivity located simultaneously in the same section of adult small intestine. $\boldsymbol{F}$, Merged image of $\boldsymbol{D}$ and $\boldsymbol{E}$. NETimmunoreactive neurons contain DBH immunoreactivity. Scale bar, $25 \mu \mathrm{m}$.

of DBH and NET were located in the adult small intestine (Fig. $4 D-F)$. As was the case with $\mathrm{TH}$ immunoreactivity, the immunoreactivities of DBH and NET were coincident, all of the NET-immunoreactive cells were also DBH immunoreactive, and all of the doubly labeled DBH/NET-immunoreactive cells were located in the region of the primordial ENS. The cells of the E12 bowel that express NET, therefore, are probably TC cells.

\section{Neurons that develop from transiently catecholaminergic precursors express NET}

All of the terminally differentiated serotonergic neurons of the ENS arise from TC cell precursors (Baetge et al., 1990; Blaugrund et al., 1996). Serotonergic neurons, moreover, continue to express $\mathrm{DBH}$ despite their noncatecholaminergic phenotype. To determine whether NET-expressing TC cells give rise to NETexpressing neurons, in situ hybridization was used to detect transcripts expressing NET, and 5-HT was immunocytochemically located in the same sections of an adult gut (Fig. 5A-C). Expression of transcripts encoding NET was found to be coincident with 5-HT immunoreactivity. Although all 5-HT-containing cells expressed transcripts encoding NET, only $32 \%$ of NET-expressing cells were 5-HT immunoreactive. These observations are consistent with the ideas that NET-expressing TC precursors do, in fact, give rise to noncatecholaminergic terminally differentiated neurons that continue to express NET and that a subset of such neurons is serotonergic; however, additional NET-expressing successors to TC cells, which are not serotonergic, must also exist. Some of these additional successors might be calretinincontaining neurons. A subset of calretinin-containing neurons was found to express $\mathrm{DBH}$, which is completely coincident with NET in the adult bowel, thereby suggesting that a subset of calretinin-containing neurons must also coexpress NET. To determine whether their expression of NET caused calretininexpressing neurons to be sensitive to the toxic effects of 6-hydroxydopamine, the uptake of which is NET-dependent, calretinin immunoreactivity was demonstrated in laminar preparations of gut that had been subjected to chemical sympathectomy with 6-hydroxydopamine (supplemental Fig. 1, available at www. jneurosci.org as supplemental material). Although 6-hydroxydopamine ablated sympathetic axons, the numbers of the neurons with calretinin $(63.3 \pm 7.0$ neurons $/ \mathrm{mm}^{2}$ ) or neuronal nitric oxide synthase (nNOS) $\left(38.0 \pm 2.6\right.$ neurons $\left./ \mathrm{mm}^{2}\right)$ immunoreactivities in control preparations were not significantly different from the numbers of those with calretinin immunoreactivity (63.0 \pm 9.4 neurons/ $\mathrm{mm}^{2}$ ) or nNOS immunoreactivity $\left(37.7 \pm 5.0\right.$ neurons $\left./ \mathrm{mm}^{2}\right)$ in animals treated with 6-hydroxydopamine (supplemental Fig. $1 A$, available at www.jneurosci. org as supplemental material); nevertheless, 6-hydroxydopamine did cause a significant enlargement of the varicosities of both calretinin-immunoreactive $(1.31 \pm 0.04$ $\mu \mathrm{m}$ in control vs $2.24 \pm 0.04 \mu \mathrm{m}$ after 6-hydroxydopamine; $p<0.001)$ and nNOS- immunoreactive $(0.98 \pm 0.03 \mu \mathrm{m}$ in control vs $1.52 \pm 0.04 \mu \mathrm{m}$ after 6-hydroxydopamine; $p<0.001$ ) axons (supplemental Fig. $1 B$, available at www.jneurosci.org as supplemental material). These observations suggest that the NET that calretininand nNOS-containing neurons express is functional and leads to sufficient uptake of 6-hydroxydopamine to cause swelling of axonal varicosities; however, in contrast to sympathetic axons, the NET-mediated uptake of 6-hydroxydopamine in calretinin- and nNOS-containing neurons is insufficient to cause frank axonal degeneration. As is true also of sympathetic neuronal cell bodies, those of neither calretinin- nor nNOS-expressing neurons degenerate after chemical sympathectomy.

Calretinin-containing neurons, like serotonergic neurons, develop early in ontogeny (Chalazonitis et al., 2008), which is consistent with the idea that at least some of these neurons are TC cell derived. In the adult bowel, there was a partial colocalization of calretinin immunoreactivity with that of DBH, which is a marker of TC-cell-derived neurons (Fig. 5D-F) and, as noted above, is coincident with NET in the adult bowel. These data suggest that a subset of calretinin-containing neurons originate from precursors that are TC cells.

Nitrergic neurons have been found to develop early in ENS ontogeny and are present in the E12 mouse foregut (Branchek and Gershon, 1989; Young et al., 1999). Most of the nitrergic neurons of the myenteric plexus are born between E12.5 and E14.5, although the birthdays of nitrergic neurons extend through postnatal day 1 (P1) (Chalazonitis et al., 2008). In contrast, all the birthdays of serotonergic neurons are completed by E15 (Pham et al., 1991). To determine whether NET-expressing TC cells give rise to nitrergic neurons, NET and nNOS immunoreactivities were located in the same sections of an adult gut (Fig. $5 G-I)$. All of the nNOS-immunoreactive neurons in the bowel 
were also NET immunoreactive. The nNOS-immunoreactive neurons were a subset comprising $\sim 40 \%$ of the NETimmunoreactive cell population. As with calretinin-expressing neurons discussed above, nNOS-immunoreactive neurons were examined in laminar preparations of gut after chemical sympathectomy with 6-hydroxydopamine to determine whether their expression of NET caused them to be sensitive to 6-hydroxydopamine neurotoxicity. Again, 6-hydroxydopamine failed to alter the numbers of nNOSimmunoreactive neurons but did cause a significant enlargement of the varicosities of nNOS-immunoreactive axons.

\section{Enteric dopaminergic neurons do not express NET}

Dopaminergic neurons are among the late-born enteric neurons that are not derived from TC precursors (Li et al., 2004). They do not even begin to appear until long after TC cells have disappeared; moreover, in contrast to TC cells and their progeny, which are dependent on the Ascll transcription factor (Blaugrund et al., 1996), enteric dopaminergic neurons are Ascl1 independent (Li et al., 2004). In addition to TH expression, the expression of DAT defines dopaminergic neurons. Because $\mathrm{TH}$ immunoreactivity was used to identify TC cells in early development, DAT immunoreactivity was used as a marker for dopaminergic neurons in the mature bowel. In contrast to the immunoreactivities of 5-HT and nNOS, those of DAT and NET were not coincident (Fig. 6). Moreover, most of the DAT-immunoreactive neurons, which are dopaminergic and contain both DAT and TH (Li et al., 2004; Mongardi Fantaguzzi et al., 2009), were found in the submucosal plexus, whereas most, if not all (Fig. $4 D-F$ ), of the NETimmunoreactive neurons were myenteric.

\section{Deletion of NET interferes selectively with the development/ maintenance of subsets of enteric neurons}

The densities of total and subsets of myenteric neurons were compared in wild-type (WT) and transgenic mice lacking NET (NETKO) to determine whether NET expression is necessary for neuronal development and/or survival (Fig. 7; Table 1). NETimmunoreactive neurons were detected in preparations from WT mice, but none were found in those from NETKO animals (Fig. $7 A, B$ ). The antibodies used to demonstrate NET were thus specific. The packing density (number per square millimeter) of myenteric neurons was measured in LMMP preparations using the immunocytochemical demonstration of $\mathrm{HuC} / \mathrm{D}$ as a marker (Fig. 7C,D) and was found to be significantly decreased by $\sim 30 \%$ in NETKO mice (Table 1). To determine the types of neurons affected by the deletion of NETKO, immunocytochemically identified subsets of neurons were examined in WT and NETKO mice. 5-HT-immunoreactive (Fig. 7 E, F), calretininimmunoreactive (Fig. 7G,H), nNOS-immunoreactive (Fig. 7I,J) neurons were selected for analysis because they are born early in development and express NET, whereas TH-immunoreactive neurons were selected for comparison because they are born late in ontogeny and do not express NET (Fig. $7 K, L$ ). The packing densities of enteric serotonergic and calretinin-immunoreactive neurons were significantly decreased by $\sim 60$ and $\sim 30 \%$, respectively (Table 1). In contrast, significant reductions were not observed in the densities of either nNOS- or TH-immunoreactive neurons (Table 1).

Because 5-HT was observed in nerve fibers, albeit in very few nerve cell bodies in NETKO mice, additional studies were done to confirm the effect of the deletion of NET on the development/ maintenance of serotonergic neurons. TPH2 is selectively expressed in serotonergic neurons (Côté et al., 2003; Gershon and Tack, 2007; Gershon, 2009; Neal et al., 2009), whereas TPH1 is found in the enterochromaffin cells of the mucosal epithelium (Walther et al., 2003a; Ghia et al., 2009). Real-time PCR was thus used to quantify transcripts encoding TPH2 in the ilea of WT and NETKO mice. Data obtained for transcripts encoding TPH2 were compared with data obtained for those of TH. The levels of transcripts encoding TPH2 were significantly lower in NETKO than in WT mice; moreover, the levels in some of the NETKO animals were virtually undetectable (Fig. 8). In contrast, the deletion of NET failed to affect the abundance of transcripts encoding TH. In WT mice, the relative abundance of transcripts encoding TPH2 was significantly less than that of $\mathrm{TH}$, which parallels the relative 


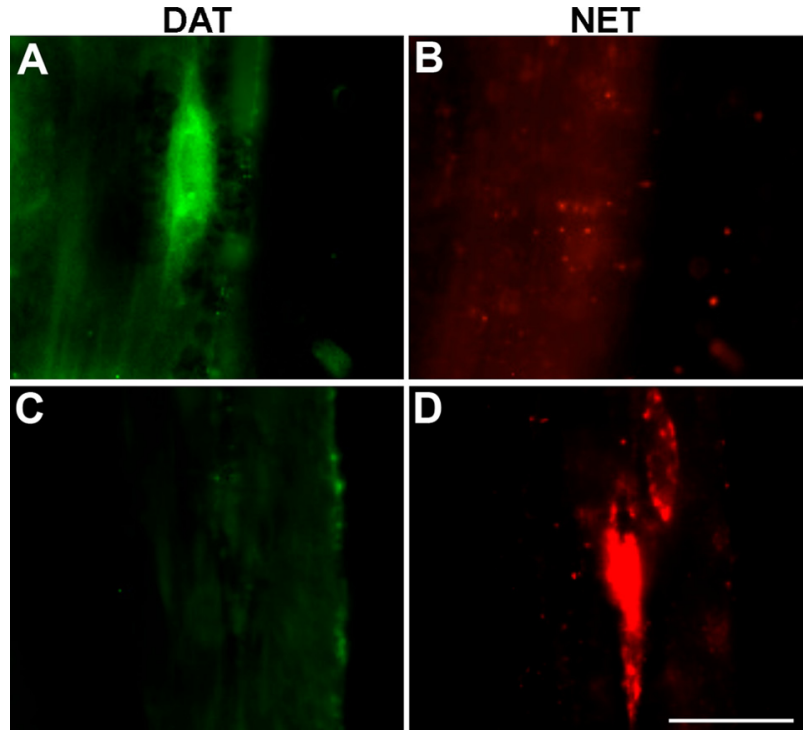

Figure 6. NET immunoreactivity is not found in enteric dopaminergic neurons. A, DAT immunoreactivity, used as a marker, demonstrates a myenteric dopaminergic neuron in adult gut. $B$, No NET immunoreactivity is found in this region of the myenteric plexus. $C$, A region of the myenteric plexus that lacks DAT immunoreactivity. $\boldsymbol{D}$, The same region contains NETimmunoreactive neurons. Scale bar, $25 \mu \mathrm{m}$.

abundance of serotonergic and dopaminergic neurons in the myenteric plexus (Table 1).

\section{Discussion}

We tested the hypotheses that the TC cells of the primordial ENS express NET and that a subset of the enteric neurons to which they give rise retain NET and require it. Subsets of noncatecholaminergic enteric neurons expressed NET and NET transcripts were detected in all regions of the mouse gut. These transcripts continued to be expressed after extrinsic denervation or chemical sympathectomy. Transcripts encoding NET were present in LMMP preparations but not in mucosa; moreover, in situ hybridization confirmed that transcripts encoding NET were located in intrinsic neurons. Immunoblotting and immunocytochemistry each detected enteric NET-immunoreactive protein, which was retained after extrinsic denervation or chemical sympathectomy. NET immunoreactivity was found only in enteric neurons that also contained NET transcripts. Enteric neurons thus appear to transcribe and translate NET and are the only cells in the gut that do so. NET immunoreactivity in the adult ENS was found in neurons identified as 5-HT or nNOS immunoreactive.

Although enteric serotonergic neurons express NET, they and their axons (Gershon et al., 1976; Costa et al., 1982; Gershon and Sherman, 1982), as well as those of nNOS- and calretinincontaining neurons survive chemical sympathectomy with 6-hydroxydopamine. 6-Hydroxydopamine caused enlargement of nNOS- and calretinin-containing varicosities, suggesting that, although these axons do not degenerate, they do take up 6-hydroxydopamine. Neither sympathetic neuronal cell bodies nor those of the NET-expressing intrinsic enteric neurons degenerate after 6-hydroxydopamine. Conceivably, the concentration of NET in the plasma membranes of sympathetic axons may be greater than that in intrinsic axons.

Enteric NET expression was detected at E10, which precedes neuronal differentiation (Rothman and Gershon, 1982; Rothman et al., 1984; Young et al., 2003) and the ingrowth of sympathetic nerves (Gershon et al., 1984). At E10, NET and p75 NTR

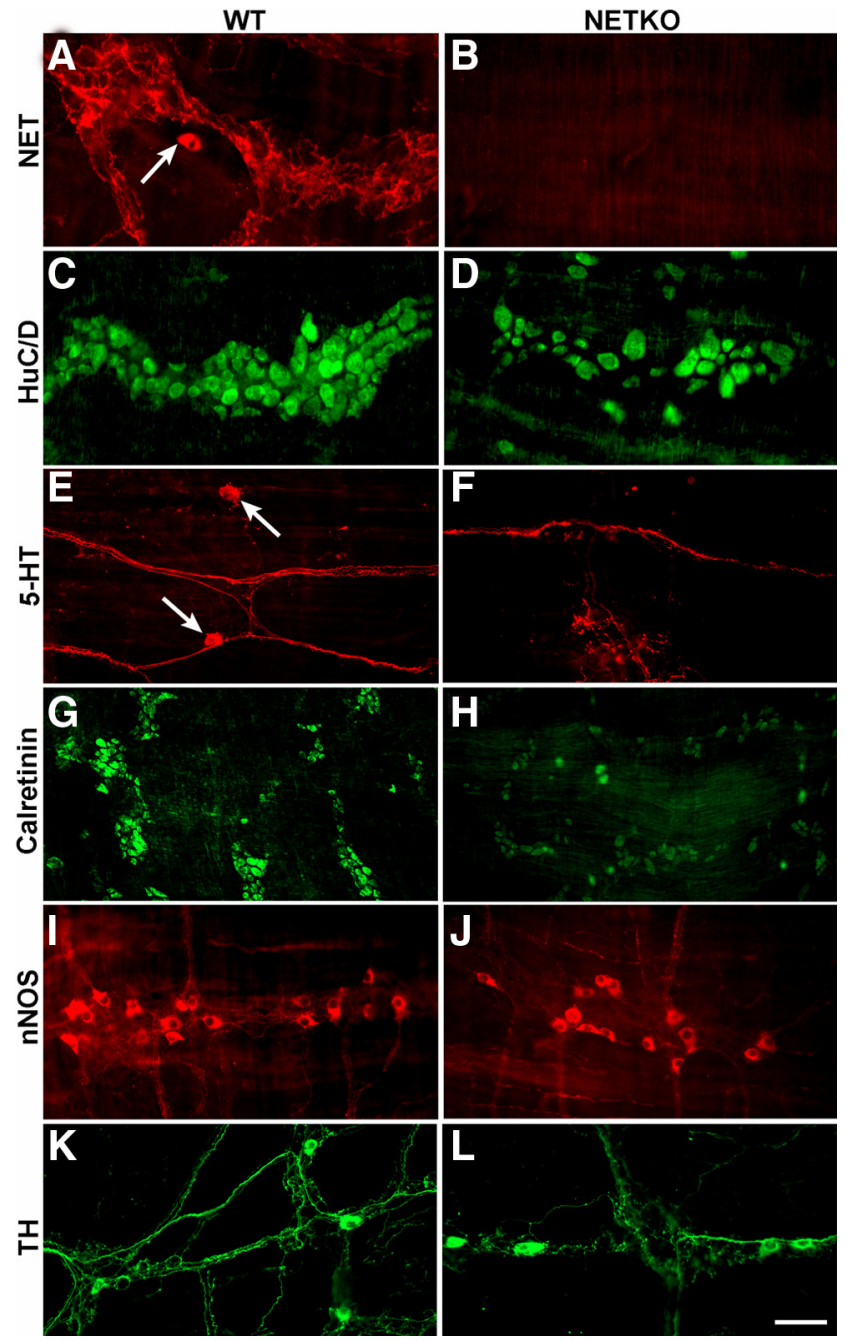

Figure 7. The knock-out of NET (NETKO mice) leads to deficiencies in total enteric neurons and in specific subsets of enteric neurons. Pairs of tissue from control mice (left: $A, C, E, G, I, K$ ) and NETKO mice (right: $\boldsymbol{B}, \boldsymbol{D}, \boldsymbol{F}, \boldsymbol{H}, \boldsymbol{J}, \boldsymbol{L}$ ) were compared immunocytochemically. $\boldsymbol{A}, \mathrm{NET}$ immunoreactivity; control mouse. A NET-immunoreactive nerve cell body is indicated by the arrow. $\boldsymbol{B}$, NET immunoreactivity; NETKO mouse. There is no immunoreactivity. C, HuC/D immunoreactivity; control mouse. D, HuC/D immunoreactivity; NETKO mouse. The density of HuC/Dimmunoreactive neurons is reduced (see Table 1). $E, 5-\mathrm{HT}$ immunoreactivity; control mouse. The arrows point to 5 -HT-immunoreactive nerve cell bodies. $F$, 5 -HT immunoreactivity; NETKO mouse. No cell bodies are immunoreactive (see Table 1). 5-HT-imunoreactive axons, however, are detectable. G, Calretinin immunoreactivity; control mouse. $\boldsymbol{H}$, Calretinin immunoreactivity; NETKO mouse. The number of calretinin-immunoreactive nerve cell bodies is reduced (see Table 1).I, nNOS immunoreactivity; control mouse. J, nNOS immunoreactivity; NETKO mouse. Similar numbers of nNOS-immunoreactive nerve cell bodies are found in control and NETKO mice (see Table 1). $\boldsymbol{K}$, TH immunoreactivity; control mouse. $\boldsymbol{L}$, TH immunoreactivity; NETKO mouse. Similar numbers of TH-immunoreactive nerve cell bodies are found in control and NETKO mice (see Table 1). Scale bar, $50 \mu \mathrm{m}$.

immunoreactivities were coincident in a subset of the p $75^{\text {NTR }}$ immunoreactive cell population, suggesting that NET-expressing cells are a subtype of ENCDCs (Fig. 9). At E12, NET immunoreactivity completely coincided with that of the TC marker TH (Teitelman et al., 1981; Gershon et al., 1984). TH disappears from the murine gut after E15 because it is not expressed by the noncatecholaminergic neurons that develop from them (Baetge and Gershon, 1989; Baetge et al., 1990). At least some of these neurons continue to express DBH, even after TH expression is lost (Fig. 9). The immunoreactivities of NET and DBH were coincident in adult bowel; moreover, NET was also found in serotonergic neu- 


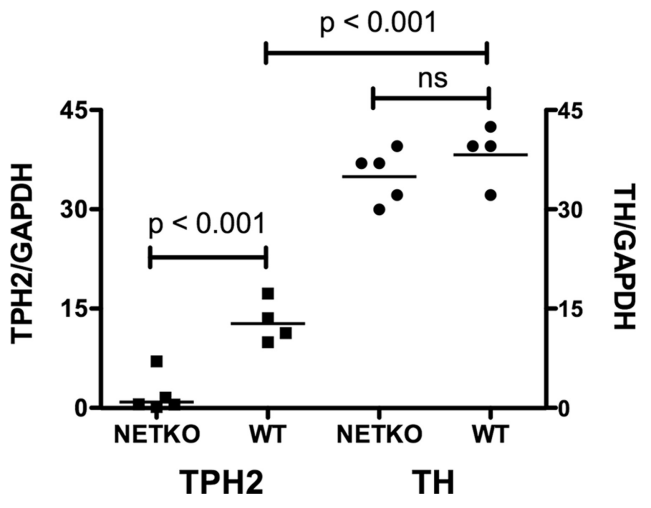

Figure 8. The abundance of transcripts encoding TPH2 is greatly reduced in the gut of NETKO mice, but that of transcripts encoding TH is similar in NETKO and WT animals. Real-time PCR was used to determine the abundance of transcripts encoding TPH2 and TH [relative to that of glyceraldehyde-3-phosphate dehydrogenase (GAPDH)] in NETKO and WT mice. The abundance of transcripts encoding TPH2 is significantly lower than that of TH probably because the gut contains fewer serotonergic than dopaminergic neurons. Transcripts encoding $\mathrm{TPH} 2$ can readily be detected in WT but not NETKO mice.

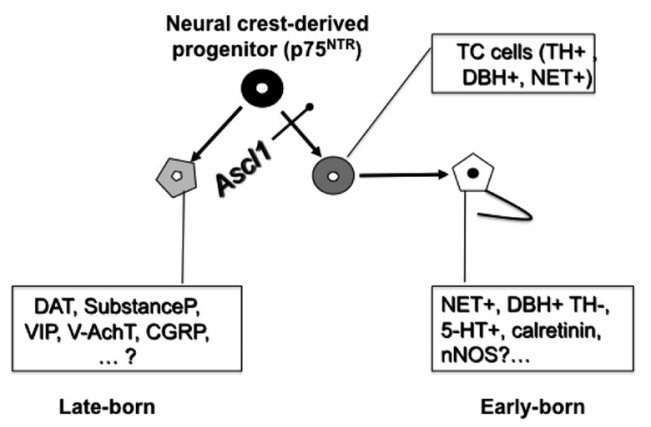

Figure 9. ENCDCs give rise to two lineages of enteric neurons. One is derived from TC cells, which is Ascl1 dependent and born early (right). The other is Ascl1 independent and born late (left). Markers expressed by precursors and terminally differentiated neurons are shown in the boxes. CGRP, Calcitonin gene-related peptide; V-AchT, vesicular acetylcholine transporter; VIP, vasoactive intestinal peptide.

rons, which are DBH immunoreactive, $A s c l$ dependent, and TC cell derived (Baetge et al., 1990; Blaugrund et al., 1996). In contrast, enteric dopaminergic neurons, which were not NET immunoreactive, are Ascl 1 independent, and non-TC cell derived (Li et al., 2004). These observations are consistent with the idea that enteric NET expression is restricted to the TC-cell-derived lineage of enteric neurons (Fig. 9).

Experiments with NETKO mice suggested that NET is required for the development and/or survival of enteric neuronal subsets. The ENS of NETKO mice contained fewer neurons than that of WT littermates. NETKO especially affected serotonergic neurons; numbers of 5-HT-immunoreactive neurons were reduced, and transcripts encoding the neuron-specific TPH2 were virtually absent (Walther et al., 2003a; Neal et al., 2009). Serotonergic neuron depletion in NETKO mice may be greater than counts of 5-HT-immunoreactive neurons suggest. Nonserotonergic neurons that express DAT or an OCT might acquire ectopic 5-HT immunoreactivity by taking up 5-HT derived from TPH1containing enterochromaffin or mast cells (Chen et al., 2001). Calretinin-immunoreactive neurons were also reduced in NETKO mice. These neurons are partially derived from TC cells and, like serotonergic neurons, are born early in ontogeny (Chalazonitis et al., 2008). Although NET and nNOS immunoreactivities were coincident in enteric neurons, NETKO did not reduce the numbers of nNOS-immunoreactive neurons, which also appear early in ontogeny. NET expression, therefore, is not essential for the development/survival of all of the neurons that express it.

It is unclear why NET expression is required for the development of only some of the enteric neurons that express it. NET appears to be essential for the development of a normal complement of sympathetic neurons, and it has been related to the acquisition of a noradrenergic phenotype (Zhang and Sieber-Blum, 1992). NET inhibitors antagonize the development of noradrenergic neurons from isolated crest cells in vitro, and when such cells are isolated from NETKO mice, they give rise to smaller numbers of noradrenergic neurons (Hu et al., 2009). Gene expression profiles of differentiating crest-derived cells have been compared. Relevant genes that are differentially expressed in WT and NETKO mice include $T h$ and $D b h$, which are significantly upregulated, suggesting that NE biosynthesis is increased in the smaller numbers of noradrenergic neurons that develop from NETKO precursors. Several genes that are potentially relevant to enteric neuronal development/survival were also found to be significantly upregulated in NETKO mice. These include Praja2 (Pra2; a RING H-2 protein with E2-dependent E3 ubiquitin ligase activity), $\mathrm{Htr} 3 \mathrm{a}$ (the functional subunit of the $5-\mathrm{HT}_{3}$ receptor), Tlx2 (T cell leukemia, homeobox 2; Hox11L.1), Cartpt [cocaine and amphetamine regulated transcript (CART) propeptide], Numbl (numb-like), ADAM10 (desintegin/metalloproteinase), and $A p p$ (amyloid precursor protein).

Praja2 ubiquitinates and thus promotes the degradation of the Smad adaptor protein Elf, which causes Smad4 expression to decrease (Saha et al., 2006). Because Smad 4 is common to TGF $\beta$ and bone morphogenetic protein (BMP) pathways (Chen et al., 2004), Smad4 downregulation inhibits signaling through both; in fact, BMP-driven promotion of the development of a noradrenergic phenotype in developing sympathetic neurons is Smad4 dependent (Morikawa et al., 2009). BMP signaling is critical not only in formation of the neural crest, sympathetic neurons and gut patterning but also in ENS development (Chalazonitis et al., 2004, 2008). Inhibition of BMP signaling during ENS ontogeny delays the exit of enteric neuronal precursors from the cell cycle (Chalazonitis et al., 2004). This effect ultimately increases numbers of enteric neurons. BMP inhibition selectively increases proportions of serotonergic or calretinin-expressing neurons while decreasing that of dopaminergic neurons (Chalazonitis et al., 2008). Praja2 upregulation, therefore, might delay BMP-induced differentiation and prolong neurogenesis in partial compensation for the NETKO-associated deficiency. Numbl (Petersen et al., 2004), ADAM10 (Jorissen et al., 2010), and App all oppose Notch signaling and prolong neuronal precursor proliferation (Johnson, 2003); thus, their upregulation in NETKO mice might be expected to reinforce that of Praja2 in prolonging neurogenesis. Deletion of Tlx2 causes the bowel to become hyperganglionic (Yamataka et al., 2001); therefore, although it affects intestinal muscle (Kapur et al., 2005), Tlx2 probably also regulates enteric neuronal precursor proliferation.

CART colocalizes with nNOS but not 5-HT in the ENS (Ellis and Mawe, 2003; Ekblad, 2006). CART is also neuroprotective. Conceivably, therefore, CART upregulation in NETKO mice protects CART-expressing neurons. NET-expressing nitrergic neurons, which contain CART, may thus develop/survive in NETKO mice more efficiently than serotonergic neurons, which lack CART. The NETKO-induced upregulation of Htr3a is interesting because the $5-\mathrm{HT}_{3}$ receptor is prominently expressed in the ENS (Johnson and Heinemann, 1995; Glatzle et al., 2002; Liu et 
al., 2002) and mediates fast serotonergic neurotransmission (Zhou and Galligan, 1999). Because NETKO mice are deficient in serotonergic neurons, $5-\mathrm{HT}_{3 \mathrm{~A}}$ upregulation may cause denervation supersensitivity. The opposite occurs when intrinsic serotonergic signaling is potentiated in the gut of mice that lack the serotonin transporter, $5-\mathrm{HT}_{3}$ receptor sensitivity is decreased, and its desensitization accelerates (Liu et al., 2002).

Although the current observations suggest that NET expression is required in ENS development and that the subset of enteric neurons that arise from TC precursors is NET dependent, future studies are needed to determine how NET effects are mediated. NET is a sodium- and chloride-dependent plasmalemmal transporter that clears secreted NE from synaptic clefts (Fritz et al., 1998; Matthies et al., 2009). NE uptake, however, may not be the only function of NET in TC cells. A developmental action of NET could be independent of NE transport. Alternatively, the ability of NET to regulate the intracellular NE concentration may be important to its developmental effects. Intracellular 5-HT, for example, is transamidated to small GTPases and cytoskeletal proteins, which provokes platelet activation (Walther et al., 2003b), pancreatic $\beta$-cell secretion (Paulmann et al., 2009), and vascular smooth muscle contraction (Guilluy et al., 2009; Watts et al., 2009). NE accumulation and subsequent monoamine oxidase A-dependent NE oxidation in heart muscle cells have been found to drive stress-associated cardiac remodeling (Kaludercic et al., 2010). Finally, depolarization is known to facilitate enteric neuronal development (Hao et al., 2010), and, because NET is electrogenic, it may also enhance development by NE-induced ion transport. The presence of TC cells in primordial gut represents a potential NE source that could affect enteric neuronal development. The absence of NE in fetal mice that lack TH (Zhou et al., 1995) or DBH (Thomas et al., 1995) is lethal at midgestation; however, lethality is thought to be caused by the loss of physiological actions of NE that maintain the cardiovascular system (Thomas et al., 1998) and protect fetuses from anoxia (Ream et al., 2008). An effect of NE on enteric neuronal development has not been reported. Conceivably, developmental effects of NE are mediated intracellularly; if so, then NET expression could provide a delivery system for circulating fetal NE.

\section{References}

Baetge G, Gershon MD (1989) Transient catecholaminergic (TC) cells in the vagus nerves and bowel of fetal mice: relationship to the development of enteric neurons. Dev Biol 132:189-211.

Baetge G, Pintar JE, Gershon MD (1990) Transiently catecholaminergic (TC) cells in the bowel of fetal rats and mice: precursors of noncatecholaminergic enteric neurons. Dev Biol 141:353-380.

Blaugrund E, Pham TD, Tennyson VM, Lo L, Sommer L, Anderson DJ, Gershon MD (1996) Distinct subpopulations of enteric neuronal progenitors defined by time of development, sympathoadrenal lineage markers, and Mash-1-dependence. Development 122:309-320.

Branchek TA, Gershon MD (1989) Time course of expression of neuropeptide $\mathrm{Y}$, calcitonin gene related peptide, and NADPH diaphorase activity in neurons of the developing murine bowel and the appearance of 5-hydroxytryptamine in mucosal enterochromaffin cells. J Comp Neurol 285:262-273.

Chalazonitis A, D'Autréaux F, Guha U, Pham TD, Faure C, Chen JJ, Roman D, Kan L, Rothman TP, Kessler JA, Gershon MD (2004) Bone morphogenetic protein-2 and -4 limit the number of enteric neurons but promote development of a TrkC-expressing neurotrophin-3-dependent subset. J Neurosci 24:4266-4282.

Chalazonitis A, Pham TD, Li Z, Roman D, Guha U, Gomes W, Kan L, Kessler JA, Gershon MD (2008) Bone morphogenetic protein regulation of enteric neuronal phenotypic diversity: relationship to timing of cell cycle exit. J Comp Neurol 509:474-492.

Chen D, Zhao M, Mundy GR (2004) Bone morphogenetic proteins. Growth Factors 22:233-241.
Chen JJ, Li Z, Pan H, Murphy DL, Tamir H, Koepsell H, Gershon MD (2001) Maintenance of serotonin in the intestinal mucosa and ganglia of mice that lack the high affinity serotonin transporter (SERT): abnormal intestinal motility and the expression of cation transporters. J Neurosci 21:6348-6361.

Costa M, Furness JB, Cuello AC, Verhofstad AA, Steinbusch HW, Elde RP (1982) Neurons with 5-hydroxytryptamine-like immunoreactivity in the enteric nervous system: their visualization and reactions to drug treatment. Neuroscience 7:351-363.

Côté F, Thévenot E, Fligny C, Fromes Y, Darmon M, Ripoche MA, Bayard E, Hanoun N, Saurini F, Lechat P, Dandolo L, Hamon M, Mallet J, Vodjdani G (2003) Disruption of the nonneuronal tph1 gene demonstrates the importance of peripheral serotonin in cardiac function. Proc Natl Acad Sci U S A 100:13525-13530.

Ekblad E (2006) CART in the enteric nervous system. Peptides 27:20242030.

Ellis LM, Mawe GM (2003) Distribution and chemical coding of cocaineand amphetamine-regulated transcript peptide (CART)-immunoreactive neurons in the guinea pig bowel. Cell Tissue Res 312:265-274.

Finch L, Haeusler G, Kuhn H, Thoenen H (1973) Rapid recovery of vascular adrenergic nerves in the rat after chemical sympathectomy with 6-hydroxydopamine. Br J Pharmacol 48:59-72.

Fritz JD, Jayanthi LD, Thoreson MA, Blakely RD (1998) Cloning and chromosomal mapping of the murine norepinephrine transporter. J Neurochem 70:2241-2251.

Furness J (2006) The enteric nervous system, Ed 2. Malden, MA: Blackwell Publishing.

Gershon MD (2009) Enteric serotonergic neurons ... finally! J Physiol 587:507.

Gershon MD, Ratcliffe EM (2006) Development of the enteric nervous system. In: Physiology of the gastrointestinal tract, Ed 4 (Johnson LR, Barrett KE, Ghishan FK, Mechant JL, Said HM, Wood JD, eds), pp 499-521. Burlington, MA: Elsevier Academic.

Gershon MD, Sherman DL (1982) Identification of and interactions between noradrenergic and serotonergic neurites in the myenteric plexus. J Comp Neurol 204:407-421.

Gershon MD, Tack J (2007) The serotonin signaling system: from basic understanding to drug development for functional GI disorders. Gastroenterology 132:397-414.

Gershon MD, Robinson RG, Ross LL (1976) Serotonin accumulation in the guinea pig's myenteric plexus: ion dependence, structure activity relationship and the effect of drugs. J Pharmacol Exp Ther 198:548-561.

Gershon MD, Rothman TP, Joh TH, Teitelman GN (1984) Transient and differential expression of aspects of the catecholaminergic phenotype during development of the fetal bowel of rats and mice. J Neurosci 4:2269-2280.

Ghia JE, Li N, Wang H, Collins M, Deng Y, El-Sharkawy RT, Côté F, Mallet J, Khan WI (2009) Serotonin has a key role in pathogenesis of experimental colitis. Gastroenterology 137:1649-1660.

Glatzle J, Sternini C, Robin C, Zittel TT, Wong H, Reeve JR Jr, Raybould HE (2002) Expression of 5-HT3 receptors in the rat gastrointestinal tract. Gastroenterology 123:217-226.

Gründemann D, Köster S, Kiefer N, Breidert T, Engelhardt M, Spitzenberger F, Obermüller N, Schömig E (1998) Transport of monoamine transmitters by the organic cation transporter type 2, OCT2. J Biol Chem 273:30915-30920.

Guilluy C, Eddahibi S, Agard C, Guignabert C, Izikki M, Tu L, Savale L, Humbert M, Fadel E, Adnot S, Loirand G, Pacaud P (2009) RhoA and Rho kinase activation in human pulmonary hypertension: role of 5-HT signaling. Am J Respir Crit Care Med 179:1151-1158.

Hao MM, Young HM (2009) Development of enteric neuron diversity. J Cell Mol Med 13:1193-1210.

Hao MM, Moore RE, Roberts RR, Nguyen T, Furness JB, Anderson RB, Young HM (2010) The role of neural activity in the migration and differentiation of enteric neuron precursors. Neurogastroenterol Motil 22:e127-e137.

Henion PD, Weston JA (1997) Timing and pattern of cell fate restrictions in the neural crest lineage. Development 124:4351-4359.

Hu YF, Caron MG, Sieber-Blum M (2009) Norepinephrine transportmediated gene expression in noradrenergic neurogenesis. BMC Genomics 10:151.

Ito K, Sieber-Blum M (1993) Pluripotent and developmentally restricted neuralcrest-derived cells in posterior visceral arches. Dev Biol 156:191-200. 
Johnson DS, Heinemann SF (1995) Detection of 5-HT3R-A, a 5-HT3 receptor subunit, in submucosal and myenteric ganglia of rat small intestine using in situ hybridization. Neurosci Lett 184:67-70.

Johnson JE (2003) Numb and Numblike control cell number during vertebrate neurogenesis. Trends Neurosci 26:395-396.

Jorissen E, Prox J, Bernreuther C, Weber S, Schwanbeck R, Serneels L, Snellinx A, Craessaerts K, Thathiah A, Tesseur I, Bartsch U, Weskamp G, Blobel CP, Glatzel M, De Strooper B, Saftig P (2010) The disintegrin/ metalloproteinase ADAM10 is essential for the establishment of the brain cortex. J Neurosci 30:4833-4844.

Kaludercic N, Takimoto E, Nagayama T, Feng N, Lai EW, Bedja D, Chen K, Gabrielson KL, Blakely RD, Shih JC, Pacak K, Kass DA, Di Lisa F, Paolocci N (2010) Monoamine oxidase A-mediated enhanced catabolism of norepinephrine contributes to adverse remodeling and pump failure in hearts with pressure overload. Circ Res 106:193-202.

Kapur RP, Clarke CM, Doggett B, Taylor BE, Baldessari A, Parisi MA, Howe DG (2005) Hox11L1 expression by precursors of enteric smooth muscle: an alternative explanation for megacecum in HOX11L1-/- mice. Pediatr Dev Pathol 8:148-161.

Laranjeira C, Pachnis V (2009) Enteric nervous system development: recent progress and future challenges. Auton Neurosci 151:61-69.

Le Douarin NM, Kalcheim C (1999) The neural crest, Ed 2. Cambridge, UK: Cambridge UP.

Li ZS, Fox-Threlkeld JE, Furness JB (1998) Innervation of intestinal arteries by axons with immunoreactivity for the vesicular acetylcholine transporter (VAChT). J Anat 192:107-117.

Li ZS, Pham TD, Tamir H, Chen JJ, Gershon MD (2004) Enteric dopaminergic neurons: definition, developmental lineage, and effects of extrinsic denervation. J Neurosci 24:1330-1339.

LiZS, Schmauss C, Cuenca A, Ratcliffe E, Gershon MD (2006) Physiological modulation of intestinal motility by enteric dopaminergic neurons and the $\mathrm{D}_{2}$ receptor: analysis of dopamine receptor expression, location, development, and function in wild-type and knock-out mice. J Neurosci 26:2798-2807.

Liu MT, Rayport S, Jiang Y, Murphy DL, Gershon MD (2002) Expression and function of 5-HT3 receptors in the enteric neurons of mice lacking the serotonin transporter. Am J Physiol Gastrointest Liver Physiol 283:G1398-G1411.

Matthies HJ, Han Q, Shields A, Wright J, Moore JL, Winder DG, Galli A, Blakely RD (2009) Subcellular localization of the antidepressantsensitive norepinephrine transporter. BMC Neurosci 10:65.

Mongardi Fantaguzzi C, Thacker M, Chiocchetti R, Furness JB (2009) Identification of neuron types in the submucosal ganglia of the mouse ileum. Cell Tissue Res 336:179-189.

Morikawa Y, Zehir A, Maska E, Deng C, Schneider MD, Mishina Y, Cserjesi P (2009) BMP signaling regulates sympathetic nervous system development through Smad4-dependent and -independent pathways. Development 136:3575-3584.

Neal KB, Parry LJ, Bornstein JC (2009) Strain-specific genetics, anatomy and function of enteric neural serotonergic pathways in inbred mice. J Physiol 587:567-586.

Pan H, Gershon MD (2000) Activation of intrinsic afferent pathways in submucosal ganglia of the guinea pig small intestine. J Neurosci 20:3295-3309.

Paulmann N, Grohmann M, Voigt JP, Bert B, Vowinckel J, Bader M, Skelin M, Jevsek M, Fink H, Rupnik M, Walther DJ (2009) Intracellular serotonin modulates insulin secretion from pancreatic beta-cells by protein serotonylation. PLoS Biol 7:e1000229.

Petersen PH, Zou K, Krauss S, Zhong W (2004) Continuing role for mouse Numb and Numbl in maintaining progenitor cells during cortical neurogenesis. Nat Neurosci 7:803-811.

Pham TD, Gershon MD, Rothman TP (1991) Time of origin of neurons in the murine enteric nervous system. J Comp Neurol 314:789-798.

Ream MA, Chandra R, Peavey M, Ray AM, Roffler-Tarlov S, Kim HG, Wetsel WC, Rockman HA, Chikaraishi DM (2008) High oxygen prevents fetal lethality due to lack of catecholamines. Am J Physiol Regul Integr Comp Physiol 295:R942-R953.

Reedy MV, Faraco CD, Erickson CA (1998a) The delayed entry of thoracic neural crest cells into the dorsolateral path is a consequence of the late emigration of melanogenic neural crest cells from the neural tube. Dev Biol 200:234-246.
Reedy MV, Faraco CD, Erickson CA (1998b) Specification and migration of melanoblasts at the vagal level and in hyperpigmented Silkie chickens. Dev Dyn 213:476-485.

Ren ZG, Pörzgen PP, Youn YH, Sieber-Blum M (2003) Ubiquitous embryonic expression of the norepinephrine transporter. Dev Neurosci 25:1-13.

Rothman TP, Gershon MD (1982) Phenotypic expression in the developing murine enteric nervous system. J Neurosci 2:381-393.

Rothman TP, Nilaver G, Gershon MD (1984) Colonization of the developing murine enteric nervous system and subsequent phenotypic expression by the precursors of peptidergic neurons. J Comp Neurol 225:13-23.

Saha T, Vardhini D, Tang Y, Katuri V, Jogunoori W, Volpe EA, Haines D, Sidawy A, Zhou X, Gallicano I, Schlegel R, Mishra B, Mishra L (2006) RING finger-dependent ubiquitination by PRAJA is dependent on TGFbeta and potentially defines the functional status of the tumor suppressor ELF. Oncogene 25:693-705.

Schaeren-Wiemers N, Gerfin-Moser A (1993) A single protocol to detect transcripts of various types and expression levels in neural tissue and cultured cells: in situ hybridization using digoxigenin-labelled cRNA probes. Histochemistry 100:431-440.

Sextier-Sainte-Claire Deville F, Ziller C, Le Douarin NM (1994) Developmental potentials of enteric neural crest-derived cells in clonal and mass cultures. Dev Biol 163:141-151.

Sieber-Blum M, Cohen AM (1980) Clonal analysis of quail neural crest cells: they are pluripotent and differentiate in vitro in the absence of non-crest cells. Dev Biol 80:96-106.

Sieber-Blum M, Ito K, Richardson MK, Langtimm CJ, Duff RS (1993) Distribution of pluripotent neural crest cells in the embryo and the role of brain-derived neurotrophic factor in the commitment to the primary sensory neuron lineage. J Neurobiol 24:173-184.

Teitelman G, Gershon MD, Rothman TP, Joh TH, Reis DJ (1981) Proliferation and distribution of cells that transiently express a catecholaminergic phenotype during development in mice and rats. Dev Biol 86:348-355.

Thomas SA, Matsumoto AM, Palmiter RD (1995) Noradrenaline is essential for mouse fetal development. Nature 374:643-646.

Thomas SA, Marck BT, Palmiter RD, Matsumoto AM (1998) Restoration of norepinephrine and reversal of phenotypes in mice lacking dopamine beta-hydroxylase. J Neurochem 70:2468-2476.

Walther DJ, Peter JU, Bashammakh S, Hörtnagl H, Voits M, Fink H, Bader M (2003a) Synthesis of serotonin by a second tryptophan hydroxylase isoform. Science 299:76.

Walther DJ, Peter JU, Winter S, Höltje M, Paulmann N, Grohmann M, Vowinckel J, Alamo-Bethencourt V, Wilhelm CS, Ahnert-Hilger G, Bader M (2003b) Serotonylation of small GTPases is a signal transduction pathway that triggers platelet alpha-granule release. Cell 115:851-862.

Watts SW, Priestley JR, Thompson JM (2009) Serotonylation of vascular proteins important to contraction. PLoS One 4:e5682.

Xu F, Gainetdinov RR, Wetsel WC, Jones SR, Bohn LM, Miller GW, Wang YM, Caron MG (2000) Mice lacking the norepinephrine transporter are supersensitive to psychostimulants. Nat Neurosci 3:465-471.

Yamataka A, Hatano M, Kobayashi H, Wang K, Miyahara K, Sueyoshi N, Miyano T (2001) Intestinal neuronal dysplasia-like pathology in Ncx/ Hox11L.1 gene-deficient mice. J Pediatr Surg 36:1293-1296.

Young HM, Ciampoli D, Hsuan J, Canty AJ (1999) Expression of Ret-, p75(NTR)-, Phox $2 \mathrm{a}-$, Phox $2 \mathrm{~b}$-, and tyrosine hydroxylase-immunoreactivity by undifferentiated neural crest-derived cells and different classes of enteric neurons in the embryonic mouse gut. Dev Dyn 216:137-152.

Young HM, Bergner AJ, Müller T (2003) Acquisition of neuronal and glial markers by neural crest-derived cells in the mouse intestine. J Comp Neurol 456:1-11.

Zhang JM, Sieber-Blum M (1992) Characterization of the norepinephrine uptake system and the role of norepinephrine in the expression of the adrenergic phenotype by quail neural crest cells in clonal culture. Brain Res 570:251-258.

Zhou QY, Quaife CJ, Palmiter RD (1995) Targeted disruption of the tyrosine hydroxylase gene reveals that catecholamines are required for mouse fetal development. Nature 374:640-643.

Zhou X, Galligan JJ (1999) Synaptic activation and properties of 5 -hydroxytryptamine3 receptors in myenteric neurons of guinea pig intestine. J Pharmacol Exp Ther 290:803-810. 